\title{
Wpływ współczesnych ruchów pionowych podłoża na zmiany parametrów geotechnicznych gruntów spoistych, niespoistych i organicznych
}

\author{
Leszek Józef Kaszubowski ${ }^{1}$
}

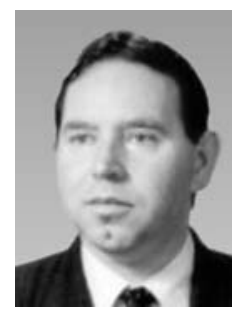

Influence of contemporary vertical movements of the soil substrate on changes of geotechnical parameters of cohesive, non-cohesive and organic soils. Prz. Geol., 69: 812-824; doi: 10.7306/2021.43

A b s $\operatorname{tr}$ a c $t$. The author presents the results of engineering-geological research carried out along of the Sierpowa St. in the area of Ostrów Grabowski in Szczecin, and along Nowomyśliwska St in Międzyzdroje. The analysis relates to geological drillings and soundings carried out using an SL for non-cohesive soils and the results of tests with the PSO-1 field rotary probe in organic soils. Additionally, the author presents examples of various geophysical investigations to recognize the influence of present-day vertical movements of the soil substrate, which have a significant effect on the instability of many parts of the existing civil engineering infrastructure, and can contribute to serious accidents or even disasters. The phenomenon of modern vertical movements of the soil substrate could have an impact on changing the geotechnical parameters of cohesive, non-cohesive and organic soils, such as the index of density (degree of density), the volume density, angle of internal friction and shear strength in the zones of compacting soils (ZDS). This dangerous phenomenon can have a negative impact on the stability of current or planned roads and highways, and building constructions. An important research element is also to learn about the characteristics of the formation of zones of decompacting soils, including the diversity of their internal structure. In the existing zones of decompacting soils, the values of the geotechnical parameters decrease. It should be noted that the genesis of the formation of modern vertical movements of the soil substrate in the micro scale, analysed by the author is not well understood and requires further detailed research.

Keywords: engineering-geological research, geotechnical parameters, soil substrate, contemporary vertical movements, zones of compacting soils, georadar research (GPR).

W artykule przedstawiono wyniki badań geologiczno-inżynierskich z obszaru Szczecina (rejon ul. Sierpowej oraz Ostrowa Grabowskiego), a także z rejonu ul. Nowomyśliwskiej w Międzyzdrojach. Natura ruchów podłoża gruntowego nie jest jeszcze w pełni dobrze rozpoznana. Można przypuszczać, na podstawie wyników licznie przeprowadzonych badań geologiczno-inżynierskich, że ma to związek z szeroko rozumianym środowiskiem gruntowo-wodnym. Do tej pory przy powstawaniu wszelkiego rodzaju awarii, a nawet katastrof $\mathrm{w}$ infrastrukturze budowlano-drogowej czy też innych obiektów, przyczyny tych wydarzeń wiązano przeważnie ze złym wykonastwem prac, zastosowaniem niewłaściwych technologii, błędami konstrukcyjnymi lub źle dobranym materiałem (Kaszubowski, 2014). W niewielkim stopniu wiązano to ze sposobem funkcjonowania środowiska naturalnego. W skali regionalnej współczesne neotektoniczne ruchy skorupy ziemskiej są przeważnie uwzględniane w przeprowadzanych badaniach geologiczno-inżynierskich podłoża gruntowego i w literaturze naukowej (Kowalski, 1968, 1975, 1988; Baraniecka, 1975; Glazer, Malinowski, 1991; Wiłun, 2013; Kaczyński, 2017). Natomiast w skali lokalnej, czy jeszcze bardziej w skali mikro, często współczesne pionowe ruchy podłoża gruntowego są pomijane. Mogą one jednak doprowadzić do osłabienia gruntów występujących ponad strefą aktywną i w efekcie być przyczyną awarii obiektów inżynierskich. Bezpośrednim efektem pionowych ruchów podłoża może być powstawanie stref zbudowanych $\mathrm{z}$ różnych gruntów, w których doszło do wzrostu ich porowatości. Autor określa to zjawisko jako rozgęszczanie gruntu. Strefy występowania takich zjawisk mają zazwy- czaj niewielkie rozmiary. W opinii autora występowanie wąskich, głębokich stref osłabienia gruntów należy wiązać z pionowymi ruchami podłoża natury grawitacyjnej w obrębie serii tworzącej podłoże gruntowe.

Dotychczas mało uwagi poświęcano w literaturze geologiczno-inżynierskiej zagadnieniom wpływu pionowych ruchów różnej genezy, w tym ruchów natury grawitacyjnej, w osadach piętra czwartorzędowego na warunki posadowienia obiektów inżynierskich takich jak drogi czy konstrukcje budowlane. Należy zaznaczyć, że w płaszczyźnie poziomej analizowane strefy występowania współczesnych ruchów pionowych podłoża, w których dokonuje się rozgęszczanie gruntów, są niedużych rozmiarów. Mają jednak istotne znaczenie dla istniejącej i projektowanej infrastruktury budowlano-drogowe. Wiercenia geologiczno-inżynierskie, jako informacja punktowa, nie były i nie są w stanie wykryć stref rozgęszczania gruntów, ponieważ nie dają możliwości prześledzenia w całości układu warstw geologicznych jako obrazu ciagłego. Jedynie badania geofizyczne, takie jak badania georadarowe, geoelektryczne czy też badania sejsmiczne, które mają możliwość ciagłego śledzenia przebiegu warstw geologicznych, mogą znacząco uzupełnić wiedzę o występowaniu takich stref, oszacować ich rozmiary oraz określić wpływ oddziaływania ruchów pionowych na zmiany parametrów gruntowych. Należy zaznaczyć, że geneza powstawania współczesnych ruchów pionowych podłoża $\mathrm{w}$ analizowanej przez autora skali mikro nie jest jeszcze dobrze poznana i wymaga dalszych, szczegółowych badań.

Celem pracy jest przedstawienie wpływu współczesnych pionowych ruchów podłoża gruntowego na zmianę

\footnotetext{
${ }^{1}$ Katedra Geotechniki, Zachodniopomorski Uniwersytet Technologiczny w Szczecinie, al. Piastów 50, 70-310 Szczecin; Leszek.Kaszubowski@zut.edu.pl
} 

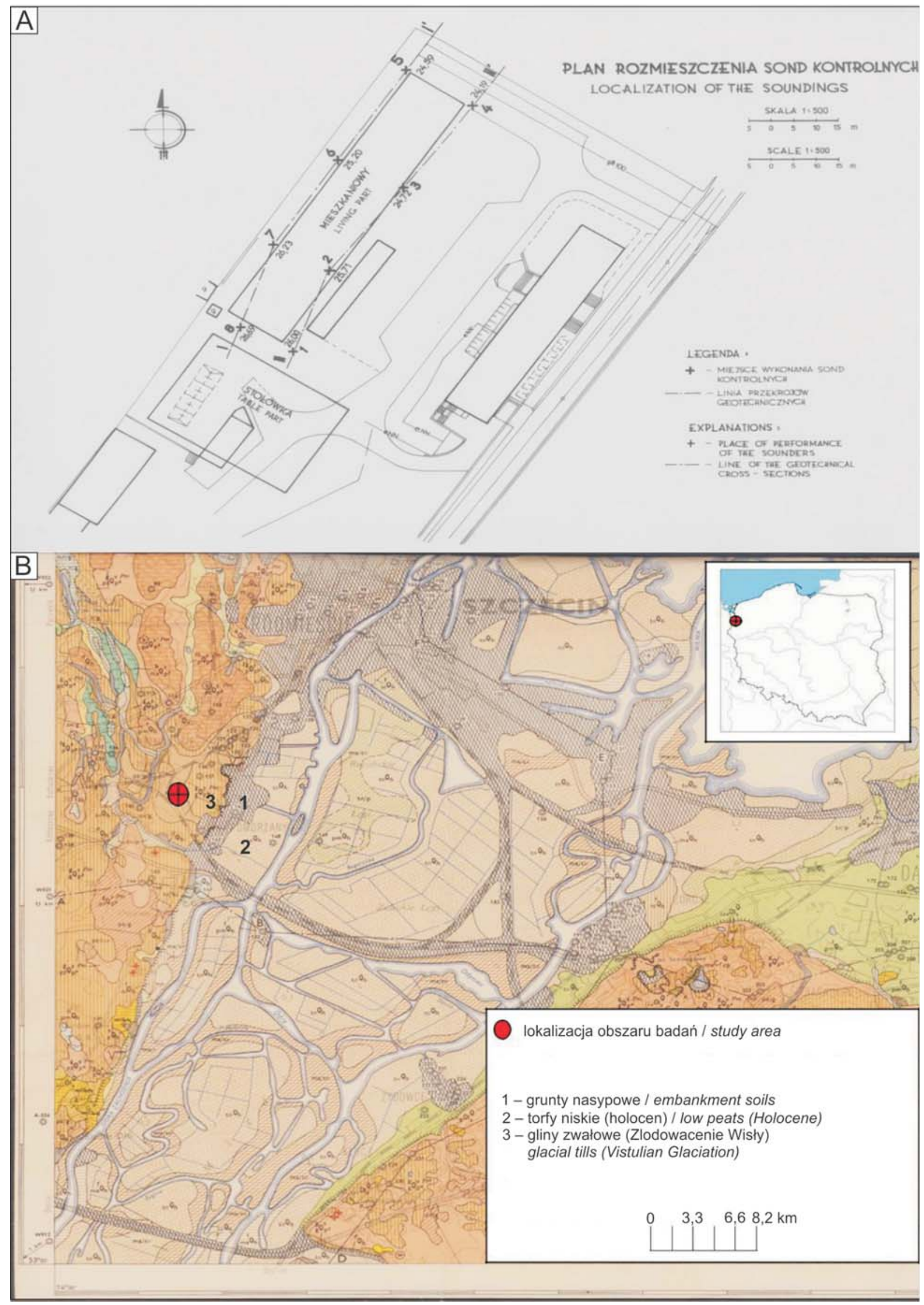

Ryc. 1. A - lokalizacja badań geologiczno-inżynierskich wzdłuż ul. Sierpowej w Szczecinie (Racinowski i in., 1987), B - obszar badań na tle Szczegółowej Mapy Geologicznej Polski, ark. Szczecin (Dobracki, 1980)

Fig. 1. A - location of engineering-geological research along Sierpowa Street in Szczecin (Racinowski et al., 1987), B - study area on the background of Detailed Geological Map of Poland, sheet Szczecin (Dobracki, 1980) 


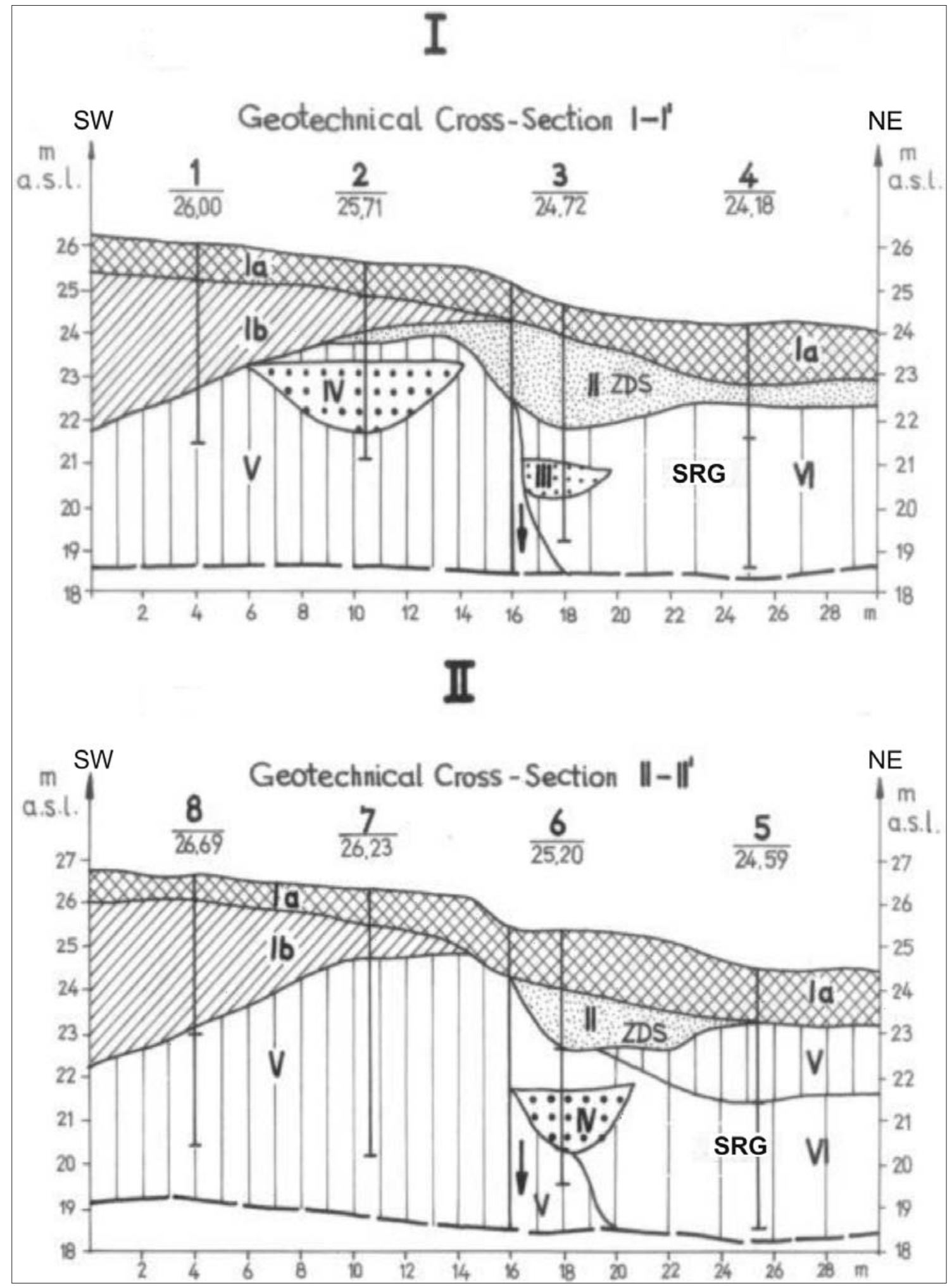

Ryc. 2. Przekroje geotechniczne w rejonie ul. Sierpowej w Szczecinie (Racinowski i in., 1987, ze zmianami autora). I - grunty nasypowe (gliny piaszczyste, piaski gliniaste, pyły piaszczyste z domieszką żwiru i gruzu, w górnych partiach piasek próchniczny), II - piasek drobny średnio zagęszczony (plejstocen), III - piasek średni średnio zagęszczony (plejstocen), IV - pospółka średnio zagęszczona (plejstocen), $\mathbf{V}$ - gliny i gliny piaszczyste twardoplastyczne (plejstocen), VI - pyły piaszczyste, gliny i gliny piaszczyste plastyczne (plejstocen), ZDS = SRG - wyznaczona przez autora strefa rozgęszczania gruntów

Fig. 2. Geotechnical cross-sections in the area of Sierpowa Street in Szczecin (Racinowski i in., 1987, modified the author). I - embankment soils (sandy gravelly silts, gravelly silty sands, sandy silts with gravel and rubble admixture, humic sands in the upper parts), II - fine sand of medium dense (Pleistocene), III - medium sand of medium dense (Pleistocene), IV - gravelly sand of medium dense (Pleistocene), $\mathbf{V}$-hard-plastic gravelly silts and sandy gravelly silts (Pleistocene), VI - plastic sandy silts, gravelly silts and sandy gravelly silts (Pleistocene), ZDS = SRG - zone of decompacting soils, recognized by the author 
parametrów geotechnicznych, a co za tym idzie, na niestabilność istniejącej infrastruktury budowlano-drogowej.

\section{MATERIALY I METODY}

W celu analizy wpływu współczesnych pionowych ruchów podłoża gruntowego na zmianę parametrów geotechnicznych wykorzystano wyniki badań geologiczno-inżynierskich przeprowadzonych na obszarze Szczecina (rejon ul. Sierpowej oraz Ostrowa Grabowskiego) oraz na obszarze Międzyzdrojów w rejonie ul. Nowomyśliwskiej. Badania geologiczno-inżynierskie w rejonie ul. Sierpowej w Szczecinie zostały wykonane za pomocą wierceń geologicznych do głębokości $6 \mathrm{~m}$ p.p.t. Natomiast na obszarze Ostrowa Grabowskiego przeprowadzono wiercenia geologiczne do głębokości $10 \mathrm{~m}$ p.p.t. oraz wykonano badania wytrzymałości na ścinanie polową sondą obrotową typu PSO-1 w podłożu gruntów organicznych, a także sondowania gruntów niespoistych sondą lekką SL. Z kolei na obszarze Międzyzdrojów w rejonie ul. Nowomyśliwskiej rozpoznanie podłoża gruntowego dokonano za pomocą 8 otworów wiertniczych i 8 sondowań. Wiercenia przeprowadzono do głębokości 4-6 m p.p.t. Sondowania wykonano sondą lekką SL z końcówką stożkową. Ponadto przeprowadzono analizy makroskopowe i badania laboratoryjne pobranych próbek gruntowych. Należy dodać, że autor zachowuje opis i nazewnictwo gruntów odnoszący się do wcześniej obowiązującej normy polskiej PN-86/B$-02480$

\section{PODLOŻE GRUNTOWE}

\section{W REJONIE UL. SIERPOWEJ W SZCZECINIE}

Badania geologiczno-inżynierskie w rejonie ul. Sierpowej w Szczecinie wykonano w celu rozpoznania podłoża gruntowego pod posadowienie ośrodka szkoleniowego (ryc. 1). Celem analizy jest wykazanie wpływu współczesnych ruchów pionowych podłoża na zmianę parametrów geotechnicznych gruntów spoistych. Istotnym elementem badawczym jest także poznanie natury zjawiska powstawania stref rozgęszczania gruntów, w tym zróżnicowania ich struktury wewnętrznej.
Podczas wcześniejszych badań (Racinowski i in., 1987) wyznaczono stopień plastyczności, gęstość objętościowa i kąt tarcia wewnętrznego w aparacie bezpośredniego ścinania. Obszar badań znajduje się w północno-zachodniej części Szczecina przy ul. Sierpowej, jest pochylony w kierunku północno-wschodnim, a deniwelacje terenu osiagają $2,50 \mathrm{~m}$. Analizowany teren jest położony w obrębie wysoczyzny moreny dennej w bliskim sąsiedztwie jej krawędzi opadającej w kierunku doliny rzeki Odry oraz doliny potoku Bukowej (ryc. 1). Powierzchnia terenu jest lekko falista. Badany teren został silnie przekształcony antropogenicznie w związku z zabudową mieszkaniową. W dolnych partiach przekroju (ryc. 2) występują gliny piaszczyste i gliny w stanie twardoplastycznym (warstwa V) oraz w stanie plastycznym (warstwa VI) należące do osadów zlodowacenia wisły. Warstwa IV jest reprezentowana przez pospółki średnio zagęszczone (ryc. 2), występujące w postaci soczewek. W otworach 2, 3, 4, 6 w budowie podłoża (ryc. 2) pojawiają się przewarstwienia piasków średnich średnio zagęszczonych (warstwa III) piasków drobnych średnio zagęszczonych (warstwa II). Są to osady glacjofluwialne. W niektórych miejscach występują przewarstwienia piasku gliniastego i pyłu piaszczystego. Górne partie przekroju (warstwa I) są zbudowane $\mathrm{z}$ gruntów nasypowych, reprezentowane przez gliny piaszczyste, piaski gliniaste i pyły piaszczyste $\mathrm{z}$ domieszką żwirów i gruzu w dolnej części, a w górnej części z piasku próchnicznego z gruzem (Racinowski i in., 1987).

\section{Interpretacja wyników badań}

Jak wynika z uzyskanych parametrów geotechnicznych (tab. 1), niektóre wartości anomalne, opisane poniżej, odbiegające od średnich, mogą świadczyć o występowaniu w rejonie otworów 3, 4, 5 (ryc. 2) stref rozgęszczania gruntów utworzonych w wyniku działania ruchów pionowych podłoża. Ich geneza nie jest jeszcze dobrze wyjaśniona i wymaga dalszych badań naukowych. W rejonie otworu 3 o istnieniu tam strefy rozgęszczania gruntów (tab. 1) może świadczyć mniejsza wartość kąta tarcia wewnętrznego piasków średnich $\left(\varphi=29^{\circ} 40^{\prime}\right)$ w stosunku do wyżej położonych piasków drobnych $\left(\varphi=31^{\circ} 00^{\prime}\right)$. Jak można przypuszczać, pierwotna wartość stopnia zagęszczenia pias-

Tab. 1. Parametry geotechniczne podłoża gruntowego przy ul. Sierpowej w Szczecinie

Table 1. Geotechnical parameters of the soil substrate along Sierpowa Street in Szczecin

\begin{tabular}{|c|c|c|c|c|c|c|}
\hline $\begin{array}{c}\text { Geotechnical } \\
\text { layer } \\
\text { Warstwa } \\
\text { geotechniczna }\end{array}$ & $\begin{array}{l}\text { Rodzaj gruntu } \\
\text { Type of soil }\end{array}$ & $\begin{array}{l}\mathbf{I}_{\mathbf{L}} \\
{[-]}\end{array}$ & $\begin{array}{l}\mathbf{I}_{\mathbf{D}} \\
{[-]}\end{array}$ & $\underset{\mathbf{g} / \mathrm{cm}^{3}}{\rho}$ & $\begin{array}{c}\varphi \\
{\left[{ }^{\circ}\right]}\end{array}$ & $\underset{[\mathrm{kPa}]}{\mathrm{Cu}}$ \\
\hline II & $\mathrm{Pd} / F S a$ & - & 0,35 & 1,75 & $31^{\circ}$ & - \\
\hline III & Ps / MSa & - & 0,40 & 2,00 & $29^{\circ} 40^{\prime}$ & - \\
\hline IV & Po / grSa & - & 0,38 & 1,90 & $32^{\circ}$ & - \\
\hline \multirow{4}{*}{ V } & Pg tpl / grsiSa hpl & 0,18 & - & 2,10 & $19^{\circ}$ & 9,0 \\
\hline & Gp tpl / saSi hpl & 0,22 & - & 2,09 & $16^{\circ} 10^{\prime}$ & 9,8 \\
\hline & Gp tpl/ sagrSi hpl & 0,17 & - & 2,15 & $16^{\circ} 50^{\prime}$ & 21,0 \\
\hline & G tpl / grSi hpl & 0,19 & - & 2,14 & $18^{\circ} 40^{\prime}$ & 17,2 \\
\hline \multirow{4}{*}{ VI } & $\mathrm{Pg} \mathrm{pl} /$ grsiSa pl & 0,40 & - & 2,08 & $17^{\circ} 20^{\prime}$ & 12,4 \\
\hline & Gp pl/saSi pl & 0,42 & - & 2,02 & $14^{\circ} 30^{\prime}$ & 8,0 \\
\hline & Gp pl / sagrSi pl & 0,38 & - & 2,07 & $13^{\circ} 40^{\prime}$ & 12,5 \\
\hline & G pl / grSi pl & 0,39 & - & 2,03 & $15^{\circ} 10^{\prime}$ & 15,0 \\
\hline
\end{tabular}

$\mathrm{I}_{\mathrm{L}}$ - stopień plastyczności, $\mathrm{I}_{\mathrm{D}}$ - stopień zagęszczenia, $\rho$ - gęstośc objętościowa, $\varphi$ - kąt tarcia wewnętrznego, Cu - kohezja

$I_{L}$ - index of plasticity, $I_{D}$ - index of density, $\rho$-volume density, $\varphi$ - angle of internal friction, $C u$ - cohesion 


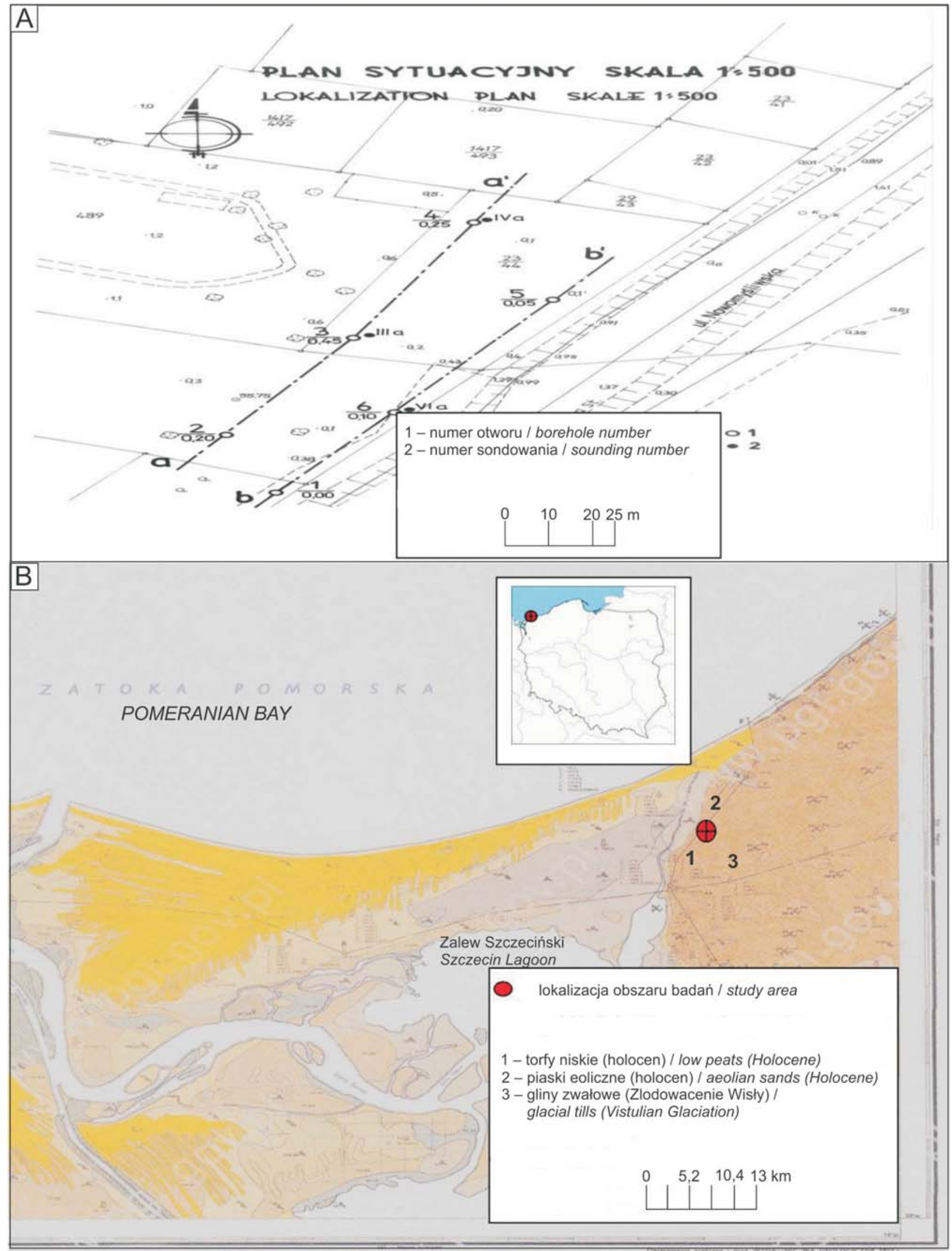

Ryc. 3. A - lokalizacja obszaru badań w Międzyzdrojach przy ul. Nowomyśliwskiej (Stopa i in., 1988), B - lokalizacja obszaru badań na tle Szczególowej Mapy Geologicznej Polski, ark. Międzyzdroje (Ruszała, Wdowiak, 1974)

Fig. 3. A - Location of the study area in Międzyzdroje at Nowomyśliwska St. (Stopa et al., 1988), B - study area on the background of Detailed Geological Map of Poland, sheet Międzyzdroje (Ruszała, Wdowiak, 1974) 
ków średnich, które zalegają tutaj na głębokości 4 m p.p.t., była zapewne większa, bowiem grunty tego rodzaju na omawianej głębokości osiągają średnio wartość $\left(\mathrm{I}_{\mathrm{D}}=0,5-\right.$ $0,6)$ często więcej, a w analizowanym przypadku tylko wartość $\mathrm{I}_{\mathrm{D}}=0,40$ (tab. 1). Ponadto $\mathrm{w}$ rejonie otworu $4 \mathrm{w}$ warstwie VI (tab. 1, ryc. 2) gliny piaszczyste osiagaja znacznie mniejsze wartości kąta tarcia wewnętrznego $(\varphi=$ $\left.=13^{\circ} 40^{\prime}\right)$ niż głębiej położone gliny $\left(\varphi=15^{\circ} 10^{\prime}\right)$, pomimo że osiaggają porównywalną wartość stopnia plastyczności. Zwykle gliny piaszczyste posiadają wyższe wartości kąta tarcia wewnętrznego niż gliny zwykłe (nazwa gliny zwykłe pochodzi z podziału geotechnicznego gruntów średnio spoistych, gdzie wydziela się gliny piaszczyste, gliny i gliny pylaste). Dodatkowym elementem wskazującym na istnienie tutaj strefy ruchów pionowych podłoża gruntowego jest najniższa rzędna na przekroju geotechnicznym II-II' przedstawiająca występowanie lokalnego zagłębienia (ryc. 2). W rejonie otworu 5 głębiej położone gliny piaszczyste (ryc. 3) w stanie plastycznym (tab. 1), należące do warstwy VI, wykazują mniejsze wartości kąta tarcia wewnętrznego $\left(\varphi=13^{\circ} 40^{\prime}\right)$ w stosunku do wyżej położonych pyłów piaszczystych $\left(\varphi=14^{\circ} 30^{\prime}\right)$, które ponadto mają nieco wyższą wartość stopnia plastyczności. O obecności w tej strefie ruchów pionowych podłoża gruntowego mogą świadczyć przedstawione wyżej wartości anomalne, jak również najniżej położony punkt terenu na przekroju geotechnicznym I-I' (ryc. 2).

Należy jeszcze dodać, że przeprowadzona analiza geologiczno-inżynierska podłoża gruntowego w rejonie ul. Bohaterów Warszawy 91 w Szczecinie wykazała, że strefa ruchów pionowych podłoża nie jest jednorodna. Może funkcjonować kilka podstref o zróżnicowanym średnim tempie przemieszczania się gruntów względem siebie (Kaszubowski, 2014). Trzeba podkreślić, że ruchy pionowe

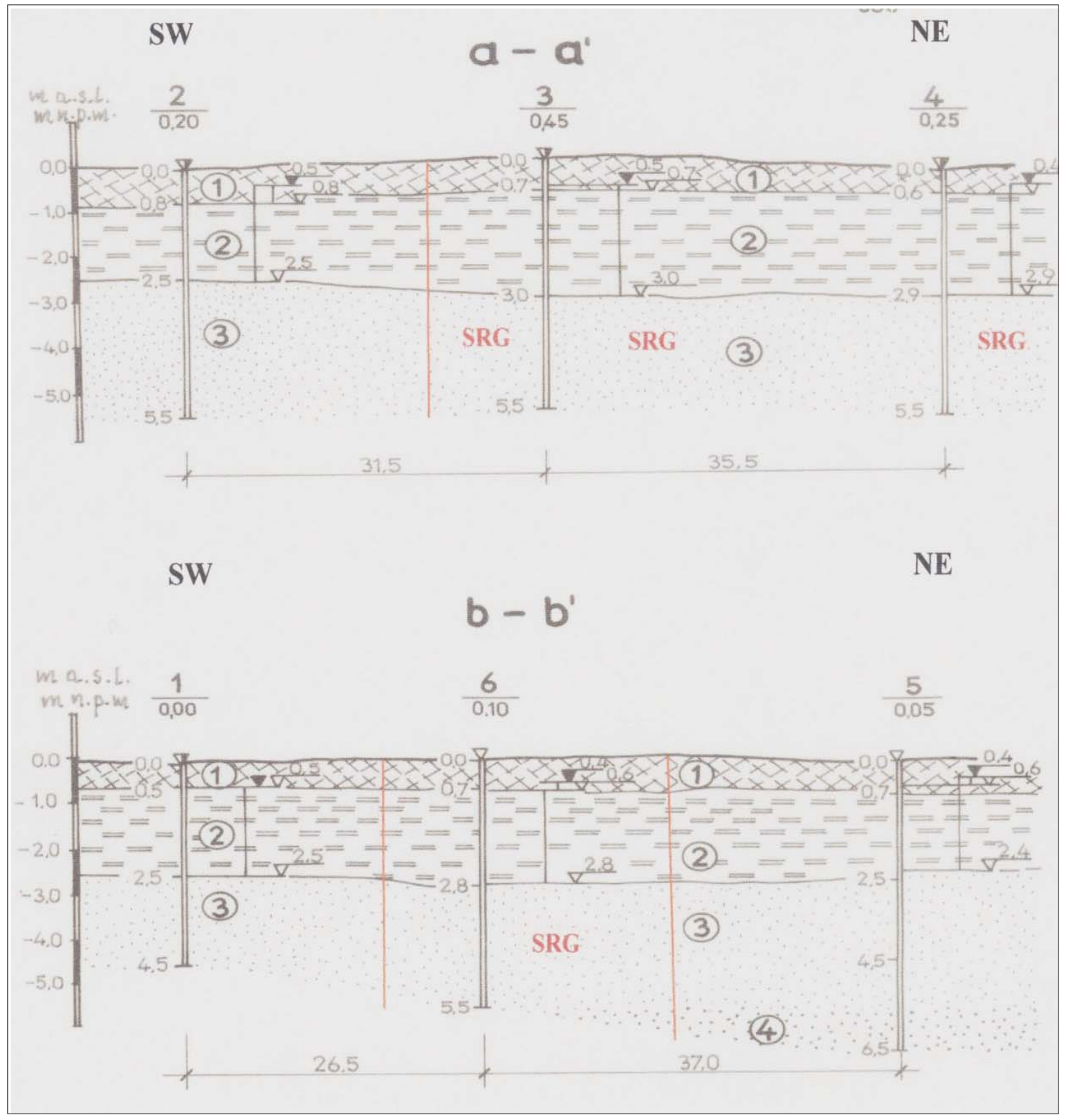

Ryc. 4. Przekroje geologiczno-inżynierskie podłoża gruntowego w Międzyzdrojach przy ul. Nowomyśliwskiej (Stopa i in., 1988). 1 - grunty nasypowe, $\mathbf{2}$ - torfy (holocen), $\mathbf{3}$ - piaski średnie, rzeczne (późny plejstocen), $\mathbf{4}$ - piaski grube, rzeczne (późny plejstocen), ZDS = SRG - strefa rozgęszczania gruntów

Fig. 4. Engineering-geological cross-sections of the soil substrate in Międzyzdroje at Nowomyśliwska St. (Stopa et al., 1988). 1 - embankment soils, $\mathbf{2}$ - peats (Holocene), $\mathbf{3}$ - fluvial medium sands (late Pleistocene), $\mathbf{4}$ - fluvial coarse sands (late Pleistocene), ZDS = SRG - zone of decompacting soils 
podłoża są groźniejsze, jeżeli występują na obszarze, gdzie utwory powierzchniowe reprezentowane są przez osady glacigeniczne (gliny zwałowe, piaski gliniaste, iły, pyły), zaliczane do gruntów spoistych.

\section{PODŁOŻE GRUNTOWE W MIEDZYZDROJACH PRZY UL. NOWOMYŚLIWSKIEJ}

Badania geologiczno-inżynierskie zostały przeprowadzone w celu rozpoznania warunków gruntowo-wodnych i wytrzymałościowych podłoża (Stopa i in., 1988) pod projektowany obiekt mieszkalny zlokalizowany w Międzyzdrojach przy ul. Nowomyśliwskiej (ryc. 3). Dokumentowany obszar jest położony w obrębie dolnej terasy akumu- lacyjnej Zalewu Szczecińskiego. Obszar terasowy jest zbudowany $\mathrm{z}$ piasków średnich pochodzenia rzecznego, tworzących się w późnym plejstocenie w czasie deglacjacji lądolodu zlodowacenia wisły. Grunty te zostały rozpoznane (ryc. 4) na głębokości od 2,5-6,5 m p.p.t i w żadnym $\mathrm{z}$ otworów nie zostały przewiercone. Omawiana warstwa geotechniczna jest zbudowana z szarych piasków średnich, średnio zagęszczonych, nawodnionych, w których występuje warstwa wodonośna ze zwierciadłem napiętym (ryc. 4). Ponad warstwą piasków średnich zalega poziom torfów mało i średnio rozłożonych (ryc. 4) z domieszką humusu i zbutwiałego drewna w stanie plastycznym. Miąższość tej warstwy waha się od 2 do $3 \mathrm{~m}$. Warstwa torfów powstała tutaj $\mathrm{w}$ holocenie jako wynik akumulacji

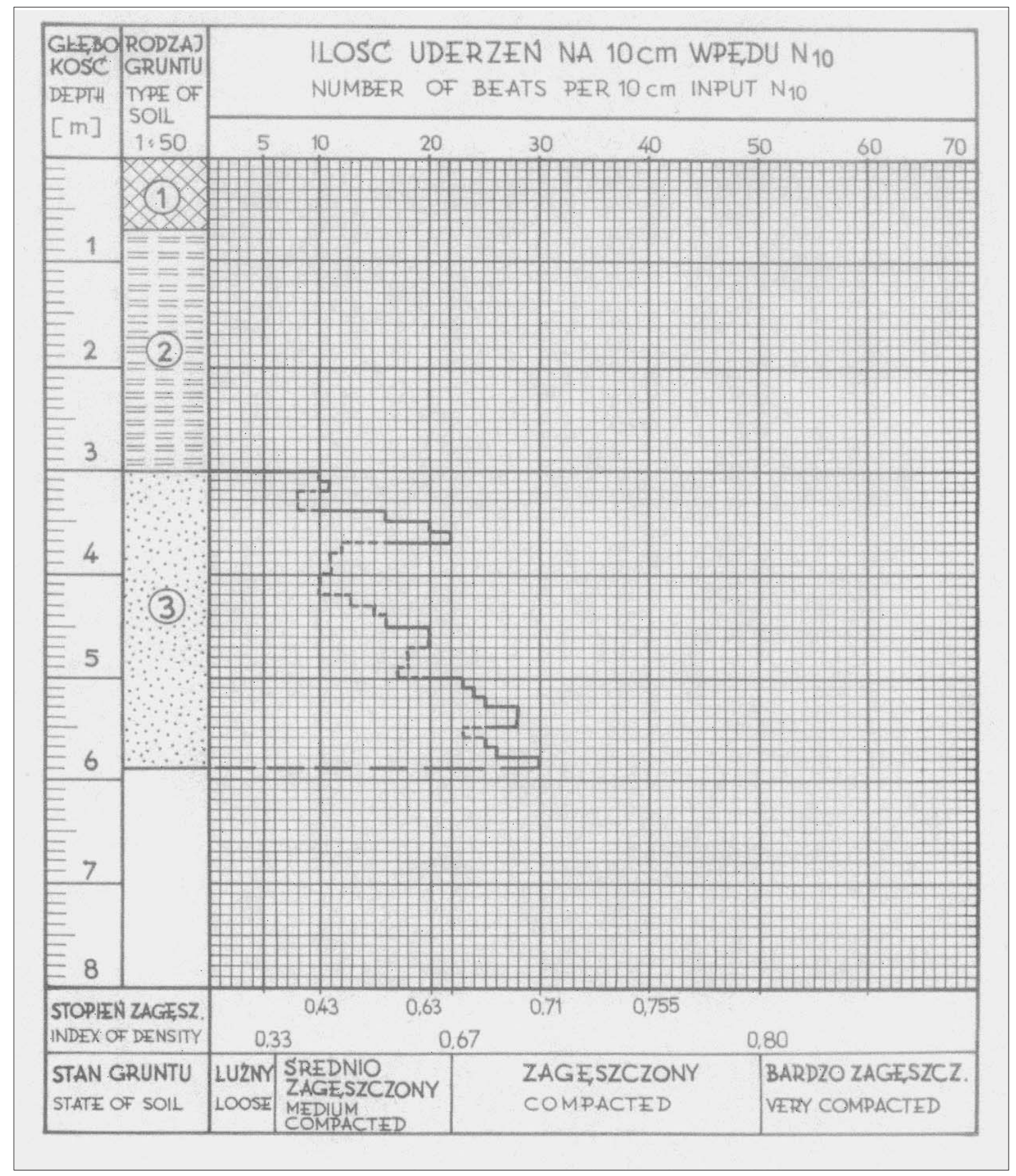

Ryc. 5. Wyniki badań stopnia zagęszczenia gruntów przy pomocy sondy lekkiej typu SL z końcówką stożkową w miejscu nr IIIa. 1 - grunty nasypowe, 2 - torfy, $\mathbf{3}$ - piaski średnie

Fig. 5. Results of the density index research of soils with the light sounder of SL type with a conical at Site No. IIIa. $\mathbf{1}$ - embankment soils, $\mathbf{2}$ - peats, $\mathbf{3}$ - medium sands 
jeziorno-bagiennej. Strop podłoża budują grunty nasypowe o niedużej miąższości dochodzącej do 0,5 m reprezentowane przez warstwę glebowo-gruzową. Nawiercone wody gruntowe w spagu torfów stabilizują się na głębokości $0,4-0,5$ m p.p.t.

\section{Interpretacja wyników badań}

Przeprowadzone w warstwie piasków średnich badania sondą lekką SL z końcówką stożkową wykazały w tej warstwie występowanie wyraźnych stref rozgęszczania gruntów. Wykres sondowania nr IIIa (ryc. 5) przedstawia wys- tępowanie strefy rozgęszczania na głębokości od 3,7 do 4,5 m p.p.t., gdzie wskazania stopnia zagęszczenia wahały się od $0,68-0,49$, wskazując na obniżenie tych wartości o $28 \%$. W głębszych partiach profilu geologicznego występowały jeszcze dwie mniejsze strefy rozgęszczania gruntów (ryc. 5). Podobne wyniki zaobserwowano w rejonie otworu nr 4, gdzie wyszczególniono również trzy strefy rozgęszczania gruntów, w których wskazania stopnia zagęszczenia zmniejszały się odpowiednio o 20,4, 36,7 i $19,0 \%$.

W miejscu sondowania nr VIa (ryc. 6) również stwierdzono występowanie strefy rozgęszczania gruntów. Strefa

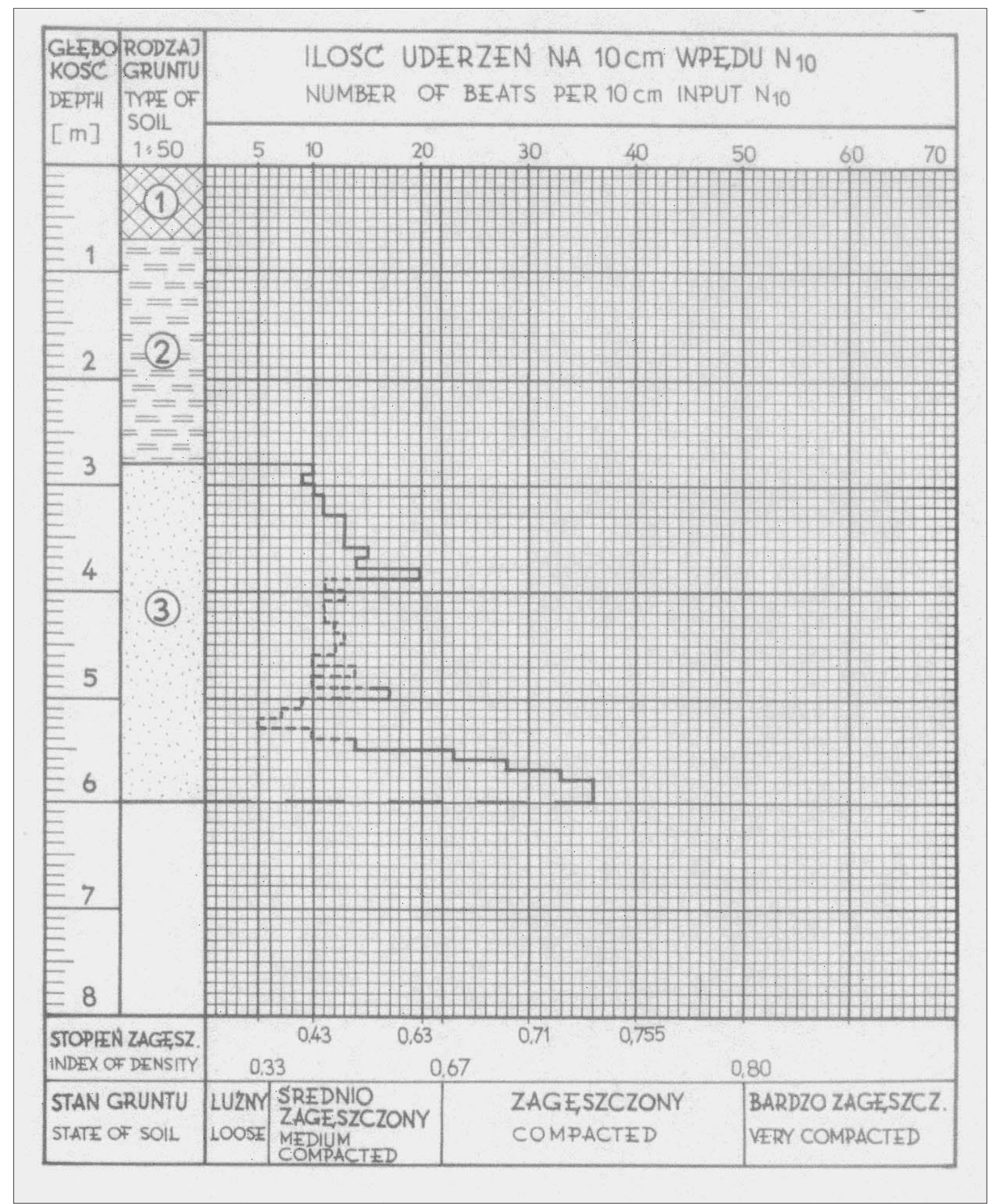

Ryc. 6. Wyniki badań stopnia zagęszczenia gruntów przy pomocy sondy lekkiej typu SL z końcówką stożkową w miejscu nr VIa. 1 - grunty nasypowe, $\mathbf{2}$ - torfy, $\mathbf{3}$ - piaski śednie

Fig. 6. Results of the index of density research of soils with the light sounder of SL type with a conical at Site No. VIa. Results of sounding No.VIa. 1 - embankment soils, $\mathbf{2}$ - peats, $\mathbf{3}$ - medium sands 


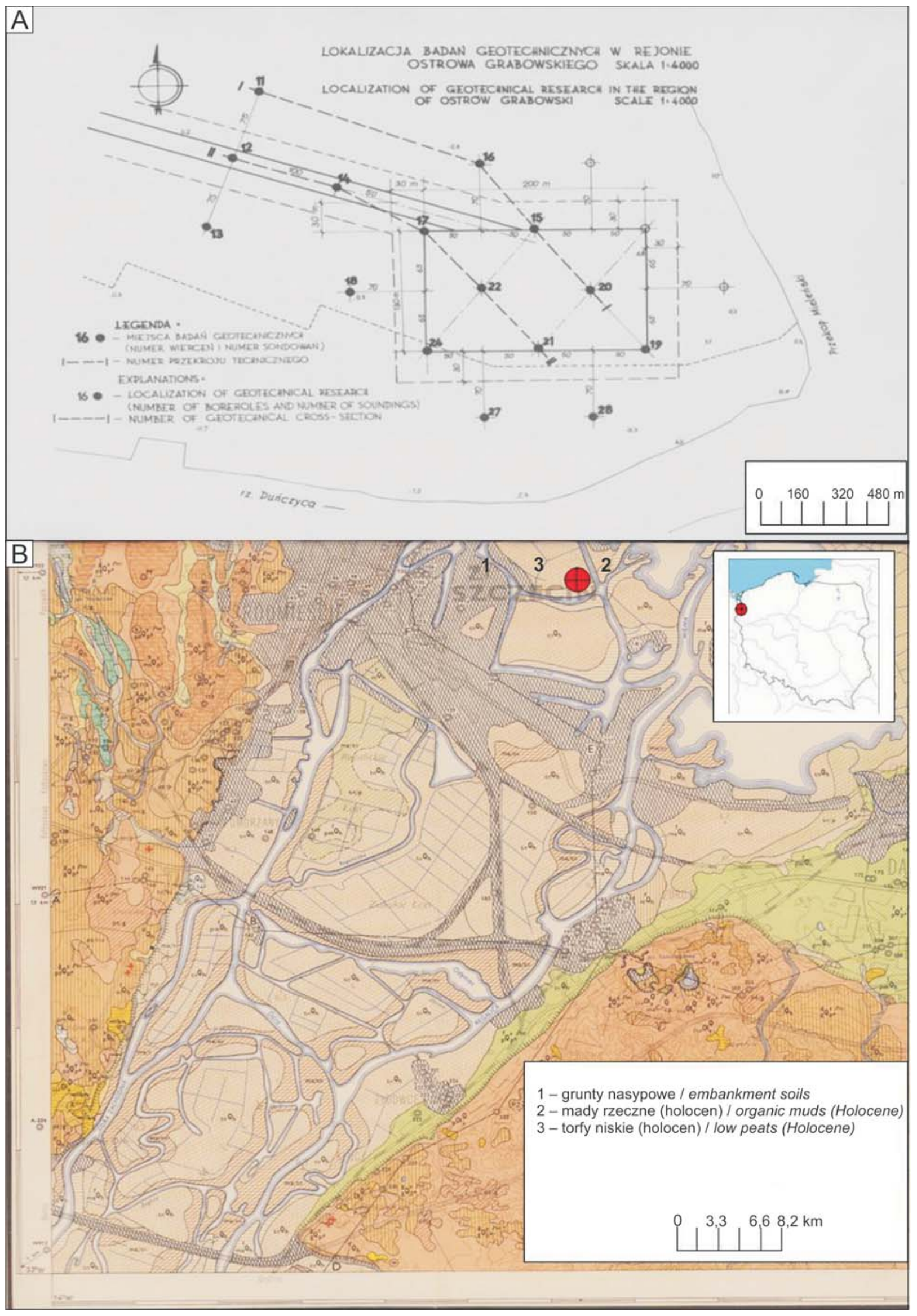

Ryc. 9. A - lokalizacja badań geologiczno-inżynierskich w rejonie Ostrowa Grabowskiego w Szczecinie (Stopa i in., 1987), B - obszar badań na tle Szczegółowej Mapy Geologicznej Polski, ark. Szczecin (Dobracki, 1980)

Fig. 9. A-location of engineering-geological research in the area of Ostrów Grabowski in Szczecin (Stopa et al., 1987), B - study area on the background of Detailed Geological Map of Poland, sheet Szczecin (Dobracki, 1980) 
ta występuje na głębokości 3,9-5,5 m p.p.t., gdzie wskazania stopnia zagęszczenia wahały się od 0,66 do 0,33 , wskazując na obniżenie tych wartości aż o $50 \%$. Należy dodać, że analizowana warstwa geotechniczna jest jednorodna pod względem litogenetycznym i stratygraficznym, dlatego jest miarodajna dla analizy zjawiska rozgęszczania gruntów. Zmniejszający się stopień zagęszczenia w strefach rozgęszczania gruntów jest przyczyną zmniejszania się wartości gęstości objętościowej, kąta tarcia wewnętrznego, czy też wytrzymałości na ścinanie.

\section{PODLOŻE GRUNTOWE W REJONIE OSTROWA GRABOWSKIEGO W SZCZECINIE}

Przeprowadzone badania geologiczno-inżynierskie podłoża gruntowego w rejonie Ostrowa Grabowskiego (ryc. 9) w Szczecinie były związane z badaniami warunków gruntowo-wodnych w celu posadowienia stanowisk statkowych oraz budowy oczyszczalni ścieków z magistralą transportową (Stopa i in., 1987). Obszar badań jest położony w południowej części wyspy Ostrów Grabowski i ograniczony od zachodu Kanałem Dębickim, od południa rzeką Duńczyca, a od wschodu Przekopem Mieleńskim. Badany obszar dotyczy najniższej terasy zalewowej rzeki Odry, płaskiej o średnich wysokościach 0,0-0,8 m n.p.m.

Dolne partie przekroju gruntowego są zbudowane z piasków drobnych pochodzenia rzecznego utworzonych we wczesnym holocenie, które są średnio zagęszczone. Nad warstwą piasków występują utwory akumulacji bagienno-rzecznej w dolnej części w postaci namułów organicz- nych o zróżnicowanej miąższości (ryc. 8), a w górnej z torfów także o zmiennej miąższości. Górne części przekroju gruntowego w niektórych miejscach budują grunty nasypowe reprezentowane przez refulowane piaski drobne i średnie, luźne z częściami organicznymi, które są nawodnione o miąższości dochodzącej do $3 \mathrm{~m}$. Strop analizowanego podłoża stanowi warstwa humusowa o miąższości od 0,2 do $1,5 \mathrm{~m}$ (ryc. 8 ).

\section{Interpretacja wyników badań}

Wyniki badań wytrzymałości na ścinanie i sondowań stopnia zagęszczenia piasków drobnych podłoża gruntów organicznych uwidoczniły niewielkie przejawy procesu rozgęszczania gruntów (prawie niezauważalne), które było można zaobserwować w rejonie otworu 16 (ryc. 8).

W warunkach naturalnych, bez nasypu konsolidacyjnego, wartości wytrzymałości na ścinanie polową sondą obrotową typu PSO-1 w torfach na głębokości 2,5 m p.p.t. oraz w namułach organicznych na głębokości 4,5 m p.p.t._osiągnęły wartość $\tau_{\mathrm{f}}=40 \mathrm{kPa}$. Należy zaznaczyć, że nieznacznie zmniejszyły się wartości tego wskaźnika w głębszych partiach warstwy 3 - na głębokości 6,5 i 8,2 m p.p.t. wytrzymałość na ścinanie osiaga wartość $\tau_{\mathrm{f}}=30 \mathrm{kPa}$. Wyniki sondowania sondą SL podłoża piaszczystego w miejscu sondowania nr XVI są przesłanką względnej stabilizacji w występowaniu tutaj ruchów pionowych podłoża, gdzie otrzymane wyniki stopnia zagęszczenia obniżyły się tylko o $10,6 \%$ w stosunku do maksymalnej wartości przedziałowej. Należy jeszcze dodać, że charakterystyczne wartości

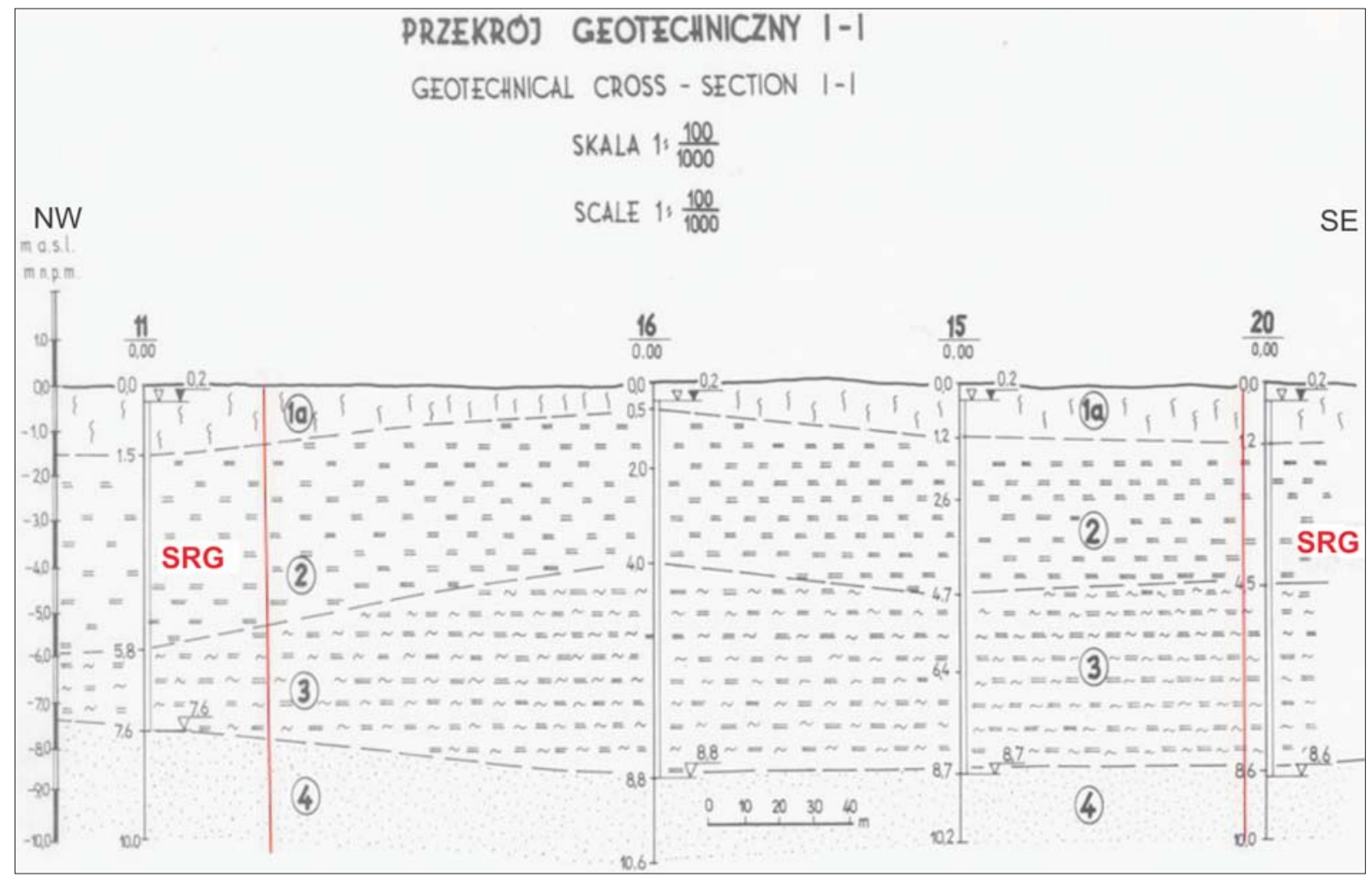

Ryc. 8. Przekrój geologiczno-inżynierski I-I w rejonie Ostrowa Grabowskiego w Szczecinie (Stopa i in., 1987). 1a - piasek humusowy (holocen), $\mathbf{2}$ - torf w stanie plastycznym (holocen), $\mathbf{3}$ - namuł organiczny w stanie plastycznym (holocen), 4 - piasek drobny rzeczny średnio zagęszczony (holocen), $\mathbf{Z D S}=\mathbf{S R G}$ - wyznaczona przez autora strefa rozgęszczania gruntów

Fig. 8. Engineering-geological cross-section I-I in the area of Ostrów Grabowski in Szczecin (Stopa et al., 1987). 1a - humic sand (Holocene), $\mathbf{2}$ - peat in the plastic state (Holocene), $\mathbf{3}$ - organic mud in the plastic state (Holocene), $\mathbf{4}$ - fluvial fine sand of medium dense (Holocene), $\mathbf{Z D S}=\mathbf{S R G}-$ zone of decompacting soils, recognized by the author 
wytrzymałości na ścinanie dla warstwy torfów i namułów organicznych w badanym terenie wynosiły ok. $50 \mathrm{kPa}$ (Stopa i in., 1987).

Z kolei wyniki badania wytrzymałości na ścinanie i sondowania podłoża piaszczystego w rejonie otworu 11 wskazują na występowanie wyraźnej strefy ruchów pionowych podłoża $\mathrm{z}$ występowaniem znacznego procesu rozgęszczania gruntów. Na wykresie wytrzymałości na ścinanie (ryc. 9) można zaobserwować duże zróżnicowanie wartości analizowanego wskaźnika. W omawianej warstwie 2, w górnych partiach torfu na głębokości $2,5 \mathrm{~m}$ p.p.t. wartość wytrzymałości na ścinanie wynosi $\tau_{\mathrm{f}}=54,4 \mathrm{kPa}$, natomiast w głębszych partiach torfu na głębokości $4,5 \mathrm{~m}$ p.p.t. wartość tego wskaźnika obniżyła się aż do $\tau_{\mathrm{f}}=16,7 \mathrm{kPa}$, wskazując na obniżenie tych wartości o $69,4 \%$ w stosunku do wielkości maksymalnej. Można założyć, że procesy biogeniczne dla całej warstwy torfu przebiegały w podobnych warunkach środowiskowych w określonym przedziale czasu. Należy dodać, że wartości wytrzymałości na ścinanie $\mathrm{w}$ warstwie namułów organicznych osiagają wynik $\tau_{\mathrm{f}}=$
$=29,3 \mathrm{kPa}$ i w stosunku do wartości typowej rezultat tego wskaźnika obniżył się o $42 \%$.

Dobrym potwierdzeniem znacznego procesu rozgęszczania gruntów w rejonie otworu 11 jest wykres sondowania piasków drobnych (ryc. 10), gdzie można zauważyć występowanie 3 stref głębokościowych rozgęszczania piasków. Pierwsza strefa występuje na głębokości 8,6-9,0 m p.p.t., gdzie wartości stopnia zagęszczenia wahały się od 0,59 do 0,56 , wskazując na obniżenie tych wartości o $5,1 \%$. W drugiej strefie (ryc. 10), na głębokości 9,1-9,9 m p.p.t., wartości stopnia zagęszczenia wahały się od 0,69 do 0,54 , wskazując na ich obniżenie o $22 \%$. Z kolei trzecia strefa (ryc. 10) występuje na głębokości 10,1-10,5 m p.p.t., gdzie wartości stopnia zagęszczenia wahały się od 0,68 do 0,56, wskazując na obniżenie tych wartości o $17,7 \%$. Należy zaznaczyć, że znaczne wartości anomalne zmniejszających się parametrów geotechnicznych wraz $\mathrm{z}$ głębokością $\mathrm{w}$ rejonie otworu $11 \mathrm{w}$ porównaniu ze względnie stabilną sytuacją podłoża gruntowego w rejonie otworu 16 dały podstawę do wyznaczenia linii wyznaczającej strefę rozgęszczania gruntów.

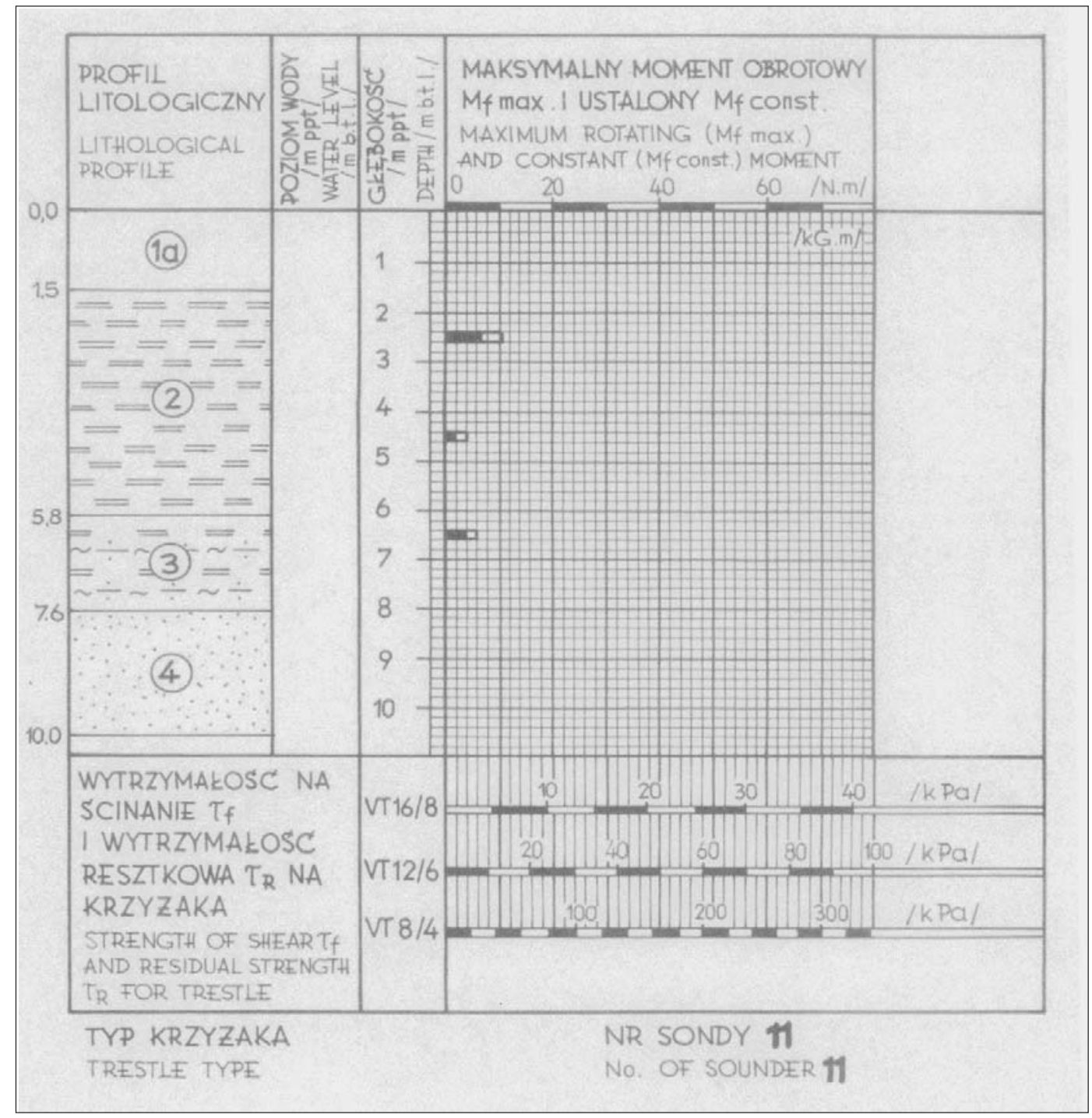

Ryc. 9. Badanie wytrzymałości na ścinanie polową sondą obrotową typu PSO-1 w miejscu nr 11 (Kaszubowski, 2017). 1a - piasek humusowy (holocen), $\mathbf{2}$ - torf w stanie plastycznym (holocen), $\mathbf{3}$ - namuł organiczny w stanie plastycznym (holocen), 4 - piasek drobny rzeczny średnio zagęszczony (holocen)

Fig. 9. Research of shear strength with the rotating PSO-1 field sounder in at Site No. 11 (Kaszubowski, 2017). $\mathbf{1 a}$ - humic sand (Holocene), $\mathbf{2}$ - peat in the plastic state (Holocene), $\mathbf{3}$ - organic mud in the plastic state (Holocene), 4 - fluvial fine sand of medium dense (Holocene) 


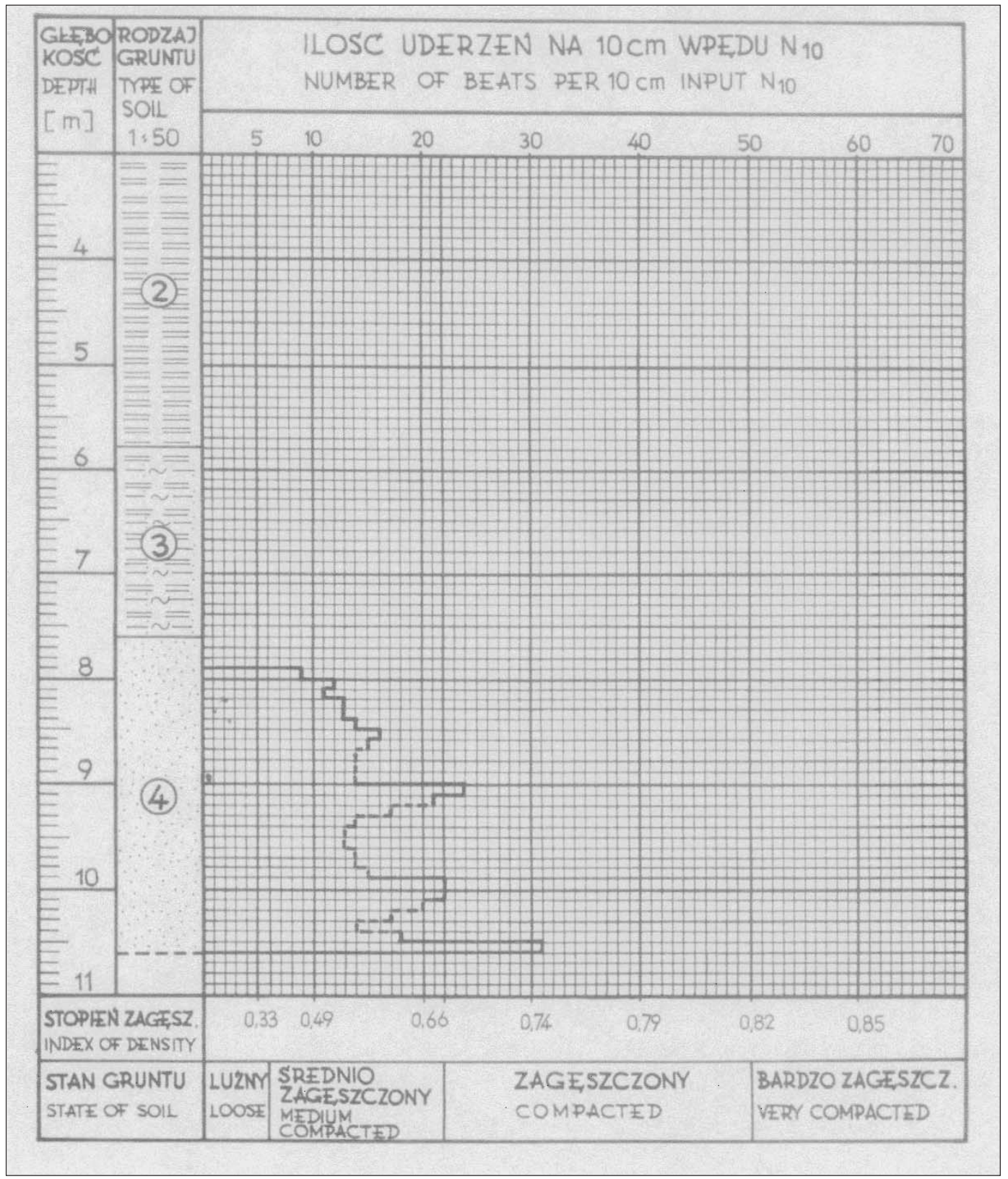

Ryc. 10. Wyniki badań stopnia zagęszczenia gruntów przy pomocy sondy lekkiej typu SL z końcówką stożkową w miejscu nr XI (Kaszubowski, 2017). 2 - torf w stanie plastycznym (holocen), $\mathbf{3}$ - namuł organiczny w stanie plastycznym (holocen), 4 - piasek drobny rzeczny średnio zagęszczony (holocen)

Fig. 10. Results of the density index research of soils with the light sounder of the SL type with a conical end at Site No. XI (Kaszubowski, 2017). 2 - peat in the plastic state (Holocene), $\mathbf{3}$ - organic mud in the plastic state (Holocene), 4 - fluvial fine sand of medium dense (Holocene)

\section{WNIOSKI}

Przeanalizowane wyniki badań geologiczno-inżynierskich podłoża gruntowego w rejonie ul. Sierpowej i Ostrowa Grabowskiego w Szczecinie oraz w rejonie ul. Nowomyśliwskiej w Międzyzdrojach pozwoliły na wyciągnięcie wniosków.

Analiza wyników badań geologiczno-inżynierskich przeprowadzonych w rejonie ul. Sierpowej w Szczecinie wykazała, że występujące w podłożu grunty spoiste w strefach rozgęszczania gruntów wywołanych ruchami pionowymi podłoża utraciły pierwotne wartości parametrów geotechnicznych, które w tym wypadku uległy zmniejszeniu, np. wartość gęstości objętościowej czy też wartość kąta tarcia wewnętrznego. To z kolei zapewne prowadzi do zmniejszenia wartości kohezji i wytrzymałości na ścinanie. Należy dodać, że ruchy pionowe podłoża są groźniejsze, jeżeli występują na obszarze, gdzie utwory powierzchniowe są zbudowane z gruntów spoistych (gliny zwałowe, piaski gliniaste, iły, pyły). W tej sytuacji w pierwszym etapie ruchów pionowych zjawisko to jest niedostrzegalne, a jedynie następuje osłabienie struktury wewnętrznej gruntów. Dopiero w późniejszym etapie osłabienie struktury wewnętrznej gruntów powierzchniowych jest już tak duże, że dochodzi do zapadnięcia się powierzchni terenu i utworzenia tam lokalnego zapadliska, powodującego powstanie awarii lub katastrofy obiektów wcześniej tam zlokalizowanych.

Pionowe ruchy podłoża powodujące powstawanie stref rozgęszczania gruntów zostały dokładnie prześledzone w badaniach stopnia zagęszczenia sondą lekką SL z koń- 
cówką stożkową w rejonie podłoża gruntowego w Międzyzdrojach przy ul. Nowomyśliwskiej. Liczne sondowania wykazały, że do głębokości 6 m p.p.t. występowało kilka stref, gdzie wskazania stopnia zagęszczenia wahały się od $10-50 \%$ utraty pierwotnych wartości. Analiza wyników badania stopnia zagęszczenia wskazała, że w istniejących strefach rozgęszczania gruntów omawiany proces może się nasilać albo zmniejszać swoje natężenie. Można także zauważyć, że strefy rozgęszczania gruntów są niejednorodne i mogą się składać z kilku zróżnicowanych części.

Badania geologiczno-inżynierskie i ich wyniki z rejonu Ostrowa Grabowskiego w Szczecinie wykazały, że tworzące się strefy rozgęszczania gruntów organicznych i ich podłoża są bardzo złożone co do przebiegu ruchów pionowych, czasu ich trwania, a nawet czasu ich powstania. Wyraźnie widać, że tworzace się w fazie inicjalnej strefy rozgęszczania gruntów charakteryzuje niewielkie zmiejszenie wartości parametrów geotechnicznych (mniej niż $10 \%)$. W istniejących strefach znacznego rozgęszczania gruntów wartości wytrzymałości na ścinanie obniżały się aż o $60 \%$ w stosunku do wartości maksymalnych lub wartości charakterystycznych. Należy dodać, że ze zmieniających się i malejących wartości wytrzymałości na ścinanie można obliczyć zmniejszające się również wartości kąta tarcia wewnętrznego i kohezji gruntów organicznych. W celu dokładniejszego prześledzenia stref rozgęszczania gruntów w analizowanym podłożu przeanalizowano także zmiany stopnia zagęszczenia piasków drobnych podścielających grunty organiczne, co może wskazywać, że strefa rozgęszczania gruntów obejmuje również warstwy położone głębiej. Analiza wykazała, że w niektórych miejscach piaski drobne rozgęściły się aż o $22 \% \mathrm{w}$ porównaniu z wartością pierwotną.

Należy przypuszczać, że proces rozgęszczania gruntów pod powierzchnią Ziemi występuje w bardzo wielu miejscach i jest niebezpieczny dla istniejącej i projektowanej infrastruktury budowlano-drogowej. Znając tempo ruchów pionowych podłoża gruntowego, można obliczyć rozmiary rozgęszczania gruntów w przeliczeniu na zmieniającą się gęstość objętościową, a z wartości wytrzymałości na ścinanie - zmiany kąta tarcia wewnętrznego i kohezji. Obliczenia tempa pionowego przemieszczania się gruntów można wykonać na podstawie wielokrotnych pomiarów wzdłuż określonego profilu sondowań sejsmicznych o wysokiej rozdzielczości.

Autor sądzi, że współczesne ruchy pionowe podłoża gruntowego przeanalizowane $\mathrm{w}$ tym artykule mogą nie mieć związku z ruchami neotektonicznymi skorupy ziemskiej. Autor przypuszcza, że może to mieć związek z anomaliami siły ciężkości przeobrażającymi się w pionowe ruchy grawitacyjne gruntów. Należy podkreślić, że niebezpieczne zjawisko współczesnych ruchów pionowych podłoża gruntowego w skali mikro nie jest jeszcze dobrze poznane, wymaga kolejnych szczegółowych badań, które dadzą odpowiedź co do genezy, rozmiaru, przyszłych tendencji rozwojowych i sposobu ich rozpoznawania.

Autor składa podziękowania Recenzentom za czas poświęcony na merytoryczną analizę treści artykułu oraz za wniesienie cennych uwag, które wpłynęły na jego formę.

\section{LITERATURA}

BARANIECKA D. 1975 - Fazy tektoniczne w czwartorzędzie środkowej części Niżu Polskiego. Materiały I Krajowego Sympozjum nt. „Współczesne i neotektoniczne ruchy skorupy ziemskiej w Polsce”, t. 1, Warszawa.

DOBRACKI R. 1980 - Szczegółowa Mapa Geologiczna Polski, ark. Szczecin. Wydaw. Geol., Warszawa.

GLAZER Z., MALINOWSKI J. 1991 - Geologia i geotechnika dla inżynierów budownictwa. PWN, Warszawa.

KACZYŃSKI R.R. 2017 - Warunki geologiczno-inżynierskie na obszarze Polski. Państw. Inst. Geol., Warszawa.

KASZUBOWSKI L.J. 2014 - Wpływ współczesnych ruchów pionowych podłoża na niestabilność infrastruktury budowlano-drogowej. Prz. Geol., 62 (10/2): 601-608.

KASZUBOWSKI L.J. 2017 - Strefy rozgeszczania gruntów podłoża budowlanego na obszarze Ostrowa Grabowskiego w Szczecinie. [W:] Meyer Z. (red.), Regionalne Problemy Inżynierii Środowiska. Wyd. ZUT, Szczecin: $33-44$.

KOWALSKI W.C. 1968 - Ruchy neotektoniczne jako czynnik kształtujący środowisko inżyniersko-geologiczne. Prz. Geol., 16 (11): 508-511.

KOWALSKI W.C. 1975 - Dynamika litosfery na obszarze Polski w okresie czwartorzędu i jej praktyczne aspekty. Materiały I Krajowego Sympozjum nt. „Współczesne i neotektoniczne ruchy skorupy ziemskiej w Polsce", t. 2, Warszawa.

KOWALSKI W.C. 1988 - Geologia inżynierska. Wyd. Geol., Warszawa. PN-86/B-02480 - Grunty budowlane, określenia, symbole, podział i opis gruntów. Polska Norma, Warszawa, 1986.

RACINOWSKI R., FRĄCZAK A., JERMOŁOWICZ P. 1987 - Opinia naukowo-techniczna dotycząca badań podłoża w miejscu planowanej rozbudowy Ośrodka Szkoleniowego przy ul. Sierpowej w Szczecinie. Arch. ZUT, Kat. Geotech., 87/7, Szczecin.

RUSZAŁA M., WDOWIAK M. 1974 - Szczegółowa Mapa Geologiczna Polski, ark. Międzyzdroje. Wydaw. Geol., Warszawa.

STOPA M., SEUL C., MACHALIŃSKI E. 1987 - Dokumentacja technicznych badań podłoża gruntowego na terenie Ostrowa Grabowskiego w Szczecinie. Arch. ZUT, Kat. Geotech., 87/26, Szczecin.

STOPA M., MACHALIŃSKI E., LEŚNIEWSKI J. 1988 - Opinia geotechniczna dotyczaca wykonania technicznych badań podłoża gruntowego wraz z określeniem warunków gruntowo-wodnych i wytrzymałościowych pod projektowany obiekt mieszkalny zlokalizowany w Międzyzdrojach przy ul. Nowomyśliwskiej. Arch. ZUT, Kat. Geotech., 88/5, Szczecin.

WIŁUN Z. 2013 - Zarys geotechniki. Wyd Komunikacji i Łączności, Warszawa.

Praca wpłynęa do redakcji 27.05.2021 r. Akceptowano do druku 2.08.2021 r. 